\title{
Management in the Luangwa Valley
}

\section{W.L. Astle}

A paper in Oryx, May 1970, Elephants or Fire -- Which to Blame?, by R.M. Lawton and Mary Gough, may have given a wrong impression of the ecological work being carried out by the Department of Wildlife, Fisheries and National Parks in the Luangwa Valley game reserves. The authors of the paper disagree with the policy of culling animals within the game reserves, and consider that the control of fire should be a primary aim in management.

I want to make a few comments on their paper, to outline the aims of our management policy in the Luangwa Valley game reserves, and to describe briefly the development taking place.

The authors suggest (page 244) that our management programmes are based on 'a few aerial reconnaissances and the advice of visiting scientists, who, although eminent in their own fields, may have little knowledge of the vegetation or habitat conditions of the area'. This is emphatically not the case. The three scientists most closely connected with the establishment and initial running of the research and management programme in the reserves have worked in Zambia on various aspects of wildlife ecology, forest ecology and range ecology for a total of forty-nine years. The policy of the Department is to welcome visiting scientists and to discuss our problems with them. But it is important, if they are not to get a wrong impression of our work, that they should be accompanied by local officers; the authors chose to work independently of the department during their brief visit to the Luangwa Valley in 1968. They take their examples of habitat utilisation from the Munyamadzi Corridor and not from within the reserves, and it is hardly surprising that they are able to write (page 245), 'our observations, on the contrary, suggest that there is no ecological evidence of habitat destruction in the Luangwa Valley to make game cropping necessary'. The well populated Munyamadzi Corridor is not at all typical of the conditions within the game reserves; it is important to realise that their paper is not based on observations of heavily utilised game habitat.

There are three game reserves in the Luangwa Valley - Luangwa South, including the Nsefu and Luambe areas, 8320 square kilometres (3200 square miles); Luangwa North, 4754 square kilometres (1790 square miles); and the Lukusuzi 2730 square kilometres 1000 square miles) which is partly on the plateau of the Eastern Province. Part of the Luangwa South reserve, the riverine area along the Luangwa River, has been developed for tourism. The department runs five small tourist camps with a total of 52 beds, to which visitors bring their own supplies and are escorted on game viewing trips, either on foot or in their own transport, by wildlife guards. Full hotel accommodation and game viewing tours are provided at the 32-bed Mfuwe Lodge, and the present concessionaries also provide 'wilderness trails', i.e. escorted three or five-

*The author is a biologist in the Zambia Department of Wildlife, Fisheries and National Parks. 
day walking safaris within the reserve, and big-game hunting safaris in adjacent areas. The reserve is open from May until the beginning of November, and has about 250 kilometres of tourist roads, In 1968 2992 visitors contributed revenue of $K 52,347$ ( $\$ 30,536)$, while safari hunting brought in another $\mathrm{K} 30,050(£ 17,534)$. We now propose to expand tourist facilities in the South Reserve by building a 120-bed lodge, a new airstrip outside the reserve, and 160 kilometres of all-season game-viewing roads, at an estimated cost of K6.3 million $(£ 3,675,000)$. No development is planned for the North Luangwa and Lukusuzi Reserves.

In 1965 a survey and research programme of work was started in the South Game Reserve to obtain factual data before drawing up management plans for the reserve and surrounding wildlife estate. But because the research programme could not yield answers to our problems for several years, interim management plans were drawn up. For example, a network of access roads and fire-breaks, some 560 kilometres, has been made in the South Reserve since 1965 because we realised that it was essential to control fires and an experimental culling programme has been completed; details may be found in the department's annual reports. Briefly, it consists of surveys of the habitats, browsing intensities, soils, and animal distribution and population structures, particularly of the major herbivores; of investigations on the diet of the major herbivores, the reaction of the vegetation to fire and browsing, and of methods of culling elephant, buffalo, hippo and impala, and the disposal of the meat.

The table shows the number of animals killed on cropping operations, according to the department's annual reports. All cropping took place in the South Reserve in areas with extremely high animal populations, and game viewing is still good in the tourist areas. The main concern was habitat protection, but meat from animals cropped was processed and sold through retailers. If culling is necessary it is only reasonable to utilise all the products. In the Luangwa Valley approximately five hundred elephants are shot each year outside the game reserves, on licence and on crop protection, and the meat is distributed locally.

John Hanks, of the National Council for Scientific Research, has carried out an outstanding investigation on the reproduction of the elephant, using culled animals, showing that the population he sampled is not increasing and appears to be static. This work is being prepared for publication. It is regrettable that the authors denigrate this type of work, which yields information impossible to obtain by other means, and moreover the conclusions of Buss and Smith, which they mention (page 244) were based on such a sample. Vegetation studies have shown that mopane woodlands are being destroyed in localised areas and the vegetation is changing to a short annual grassland. Censuses have shown elephant densities as high as $\mathbf{0 . 5}$ per square kilometre in some blocks of 2800 square kilometres, and up to 2.0 per square kilometre on smaller grass plains of 70 square kilometres. These are extremely high figures.

Although Hanks has shown that one elephant population appears to 
Table 1

ANIMALS CULLED

\section{$\begin{array}{llllll}1965 & 1966 & 1967 & 1968 & 1969 & \text { Totals }\end{array}$}

$\begin{array}{lrrrrrr}\text { Elephant } & 27 & 204 & 374 & 404 & 448 & 1453 \\ \text { Hippo } & 9 & 218 & 224 & 67 & 87 & 595 \\ \text { Buffalo } & 33 & 100 & 59 & 12 & 27 & 231 \\ \text { Impala } & 9 & - & - & 135 & 139 & \mathbf{2 8 3}\end{array}$

\begin{abstract}
Minimum estimated populations in the South Reserve
\end{abstract}

15,000
4,000
More than 15,000
More than 10,000

4,000

More than 10,000

be healthy this does not mean that we have no elephant problem. We also know that our mopane woodlands are changing into short annual grassland, and can only guess at the significance of this for the fauna. I suggest that in such a situation one should adopt a safe policy and attempt to hold animal populations artificially at a lower level. In the Luangwa this would involve a capital reduction to an arbitrary figure and an annual take-off thereafter. The optimum population is not necessarily the maximum, and if we attempt to maintain populations, I fear that our mopane woodlands may be completely destroyed. Once this happens they will require several hundred years to regenerate.

Our management policy, broadly, is to try to maintain a variety of habitat types. We fully recognise that such a simple aspiration has very involved implications and that man is the prime influence affecting our game reserves; for example, the flow of the Luangwa River is very greatly influenced by land-use practices in the headwaters region. We believe that it would be most undesirable to allow any one species to overutilise any one vegetation type or habitat, because this can only have detrimental effects on other members of the fauna. The authors are apparently not disturbed by the fact that continuous hippo grazing has reduced fine stands of the reed Phragmites mauritianus to short, three- to four-inch-high grassland, but these reed beds are not only attractive elements of the riverine zone in their own right, they are also favoured habitat of, for example, bushbuck and the pigmy kingfisher.

Big changes have undoubtedly occured in the vegetation of the game reserves over the past twenty years. The reduction of the canopy cover of mopane woodlands, which cover one third of the area, has been very marked and can be easily seen if one compares aerial photographs of 1950 with similar ones of 1965 . The authors claim that these changes are due to fire, and that high game populations reduce the danger of fire. If this thesis is correct one would expect to see more open mopane woodland outside the reserves because of fewer animals, hence more fire damage, than inside. But this is not the case, and there is no reason to think that in the past there has been any difference in the incidence of fire within and without the reserves. It was these striking vegetation changes which caused concern and led to the establishment of the initial culling programme in 1965 when twenty-seven elephant were shot, out of an estimated population of fifteen thousand. 
Within the reserves mature mopane woodland has been destroyed by local flooding in the Luangwa meander belt and by elephant ringbarking canopy trees. Heavy browsing pressure is preventing regeneration of the canopy. If there is a reduction in browsing/grazing pressure then fire control will become more important, because there will be more combustible material in the herb layer. Preferential browsing within the mopane woodlands has eliminated many of the associated woody species, and I suggest that this is not acceptable under our management objectives. The authors state (page 246) that there is a large reserve of mopane woodland in the Luangwa Valley, apparently meaning that fauna will be able to move to these other areas at some future date. One would find it difficult to write a management plan for a given area of land based on such a thesis.

The authors state that 'African wildlife has a full complement of carnivores and herbivores, which will achieve a balance provided all carnivores are not shot for trophies'. This is an over-simplification of the natural fluctuations of animal populations and, in any case, is hardly relevant to the problems of elephant ecology. Once an area is declared a sanctuary a major management decision has been made, Whatever happens within the sanctuary may be very largely determined by man's activities outside its boundaries. Therefore in our area the whole concept of inviolate sanctuaries is largely artificial. The numbers of animals within the sanctuary may be very inflated by immigration and it is this which may lead to the striking habitat changes that have occurred in some areas within the South Game Reserve.

If parts of the reserves are utilised for tourism then the tourist area must, of economic necessity, be intensively managed. Once a tourist lodge is built and an expensive game-viewing road network established, one cannot afford to risk the destruction of vegetation in this area, even though such destruction may be insignificant for an animal such as the elephant. The authors also recommend (page 247) that "parts of game reserves and national parks that have a rich fauna and flora should be set aside as sanctuaries and only patrolled by members of the game department. Similarly areas with rare or uncommon species should be made sanctuaries'. This, of course, is what was done in Zambia in 1937 when the Luangwa reserves were established. Game stocks have built up since that date by natural increase and by immigration from outside; some species have come to dominate the range and some habitats have begun to disintegrate. We do not know what the next stages will be if no controlling factors are imposed.

The authors (page 245) ask what effect cropping schemes and shooting for scientific purposes may have on local people, who have been urged to create game reserves and protect the animals completely. The reaction has indeed been one of suspicion, which in a way is gratifying because it demonstrates their interest in a national asset without which game reserves cannot survive. We hope that we will be able to explain the new concept of intensive wildlife management as successfully as we have managed to put across the basic idea of setting aside the wildlife reserves in the first place.

It is not possible to answer the question 'Elephants or Fire - Which to Blame?' The question has no meaning. Culling is only one aspect of 
management of the Luangwa Reserves, one which has caused considerable emotional controversy and adverse comment, mostly from those who have never visited the area. But if one accepts the concept of game reserve management then one must consider all the relevant ecological and economic factors, and not overemphasise any particular one.

\section{New National Parks}

This year Zambia has created 16 new national parks to add to the one already in existence, the Kafue. Together they cover 23,000 square miles, which represents eight per cent of the area of the whole country. They include three in the Luangwa Valley, Blue Lagoon and Lochinvar.

The first German national park, the Bayerischer Wald, was declared last October, although it does not yet fulfil all the international conditions of a wildlife reserve. Lynx, moose and otter presented by the Frankfurt Zoological Society, are among the first re-introductions.

The President of Senegal has informed WWF of the creation of a third national park in northern Senegal, in the Djoudj, primarily to protect birds.

\section{Finnish Park Quadrupled}

The Lemmenjoki National Park in Finland has been enlarged from 385 square kilometres to 1720 , and is now the largest in Finland and the fifth largest in Europe, extending to the Norwegian border. There are plans for a contiguous reserve in Norway, and the two together would cover a total area of $2480 \mathrm{sq}$. $\mathrm{km}$. Less good news from Finland is that Parliament has retained the bounties for wolf and wolverine in the region where they are most numerous.

\section{Reserves by Lake Baikal}

Twenty-five million acres of forest round Lake Baikal, in Siberia, are being set aside to become the Soviet Union's largest national park. Much of it will be developed for tourism, but $1 \frac{1}{4}$ million acres are being set aside for wildlife reserves, and a large reserve on the estuary of the River Selenga, the main river feeding Lake Baikal, will protect sable, marten, roe and musk deer among other animals. Lake Baikal is the world's deepest lake.

\section{New Act and Parks in Norway}

A new conservation Act in Norway requires anyone planning 'major works, constructions, or operations causing damage to Nature or the landscape', to submit the project to the conservation authorities for approval. Four new national parks have been declared: Upper Pasvik and Stabbursdalen in Finnmark, in the north-east; Aanderdale, on the large island of Senja; and Gressaamoen, north of Trondheim.

\section{'Natural Areas' in Hawaii}

A bill providing for the creation of a system of 'natural areas' and a commission to advise the State Department of Land and Natural Resources on their selection and management was passed last year by the Hawaii State Legislature. Some areas have already been selected for consideration, one of over 50,000 acres on Hawaii Island and one of 465 acres on Kaui. Two other bills enacted last year included one to protect the environment and another creating a special commission to advise the Fish and Game Division on proposals for introductions of exotic animals. 


\section{Sanctuary in Swaziland}

Mlilwane, the only wildlife sanctuary in Swaziland, created by Terence Reilly on his own farm and now extended by the purchase of neighbouring land, is increasingly successful. Sixty families on the new land and their domestic stock have been successfully resettled outside the reserve, twelve miles of road constructed and the entire area is now constantly patrolled, with the result that grey and red duikers, reedbuck, steenbuck and rock hyrax have all come back.

\section{Dolphins Chat on Atlantic Voyage}

At a conference in London in June to discuss the transport of exotic animals, the Curator of the Harderwijk Dolphinarium, Dr Dudok van Heel, described and illustrated with a film how dolphins are successfully brought across the Atlantic. Each dolphin lies in an open-topped plastic cocoon, which is kept wet, and these are laid side by side so that the animals can 'speak' to one another during the journey - which they constantly do. The keeper visits the dolphins frequently and they respond by trying to recall him at the end of each visit. With this care and attention no single dolphin has been lost on the journey. Lt Col Boyle represented the FPS at the meeting, which was organised by the Federation of Zoological Gardens. The Proceedings, price $\$ 1$, US \$2.45, including UK postage, can be obtained from Mrs J. Wilkins, 20 Manor Mansions, Belsize Grove, London NW3 4NB.

\section{Attention to Wolves}

The Survival Service Commission of IUCN has set up a specialist Wolf Group to promote wolf conservation, chaired by Prof Douglas Pimlott. In Manitoba the timber wolf has been chosen as the official symbol of the Department of Mines and Resources - sign of a new attitude towards wolves, which has also led to creation of a group called the Canadian and American Wolf Defenders. They publish a monthly newsletter called $\mathrm{Howl}$, in which Farley Mowat recently described how, on a visit to Russia, he discovered that his book Never Cry Wolf had been translated with the title Wolves, Don't Cry! In the USSR, he says, the wolf is now fully protected (since 1969); the only grounds for control being where domestic reindeer herds are threatened, and then only by government hunters.

\section{Reptiles and Amphibians}

A Conservation Committee to collect information on the important remaining habitats for amphibians and reptiles, which are sadly decreasing in Britain, has been set up by the British Herpetological Society. The Committee has applied for a WWF grant to enable it to protect as many sites as possible, working in cooperation with the Nature Conservancy and the County Naturalists' Trusts. Anyone prepared to help, or wanting advice on amphibian and reptile conservation, should write to the chairman: M. R. K. Lambert, British Herpetological Society, c/o the Zoo, Regent's Park, London, NW1 4RY.

\section{Shortage}

The FPS office would be glad to receive spare copies of Oryx Volume X, No. 3, December 1969. 